\title{
Chapter 14 \\ Learning for Peace: Lessons Learned \\ from UNICEF's Peacebuilding, Education, and Advocacy in Conflict-Affected Context \\ Programme
}

\author{
Friedrich W. Affolter and Anna Azaryeva Valente
}

\begin{abstract}
There is now widespread international recognition of the need for conflict sensitivity in programming and factoring in considerations of conflict and peace into programme design, implementation, and monitoring and evaluation. The need for such programme and policy guidance for administrative and social services is clear: precious resources need to be spent responsibly and wisely in peacebuilding settings to meet the panoply of recovery needs and priorities in ways that address conflict drivers and lay the conditions for sustainable peace. Failing to do this will undermine peacebuilding and statebuilding goals.
\end{abstract}

(McCandless, 2012, p. 1)

\subsection{Insecurity: The Primary Development Challenge of Our Time}

In the second decade of the twenty-first century, a combination of several global challenges - including climate change, conflict, chronic poverty and disease, inequality and unfairness, economic shocks, and weak institutions - is creating new risks or exacerbating existing ones, including the erosion of social cohesion and peace, the reversal of development gains, and the creation of new humanitarian needs (World Economic Forum, 2018). Fragile states - where two-thirds of the worlds poor will be residing by 2030 (44\% of them being youth below 20 years of age) - will be particularly affected (Office of Economic Cooperation and

Disclaimer: The views and opinions contained in this document are the authors' personal views and opinions and do not necessarily represent the positions of UNICEF or any other organization.

F. W. Affolter $(\triangle) \cdot$ A. Azaryeva Valente

United Nations Children's Fund, New York, NY, USA

e-mail: faffolter@unicef.org 
Development [OECD], 2015, pp. 13, 84). According to the World Bank Group (2011), insecurity “. .. is the primary development challenge of our time" (p. 1).

The costs of conflict are enormous. In human terms, vulnerable groups such as children and their caretakers pay the highest price for war and are the ones likely to benefit the most from peace. According to Save the Children, approximately 357 million children lived in countries and areas affected by war in 2016, which is 1 out of 6 of the world's children. Out of these children, 165 million were affected by high-intensity conflicts (Kirollos, Anning, Fylkesnes, \& Denselow, 2018, p. 7). Around 16 million babies were born into conflict in 2015 alone (UNICEF, 2015b). A child in a fragile or conflict-affected state was nearly three times more likely to be out of primary school, two times more likely to be undernourished, and nearly twice as likely to die before his or her fifth birthday, compared to a child in another developing country (World Bank, 2011, p. 5).

Both direct and structural violence denies children their right to protection and development of their full potential and to participate freely and fully in cultural life in conditions of equality, human dignity, and non-discrimination (Dawes \& van der Merwe, 2014, p. 236; Punamäki, 2014; United Nations General Assembly [UNGA], 2016; Human Rights Council, 2016, par. 41, 44). Exposure of children and young people to abuse in high-violence contexts is associated with an increased risk of impaired physical and mental development and increased chances to either transform into a perpetrator of violence or become a victim of violence later in life (United Nations [UN] \& World Bank Group, 2017, p. 17 ). Emerging evidence suggests that both poverty and adverse life experiences may result in long-term physiological and epigenetic effects on brain development and cognition in young children (Black et al., 2017, p. 77; Punamäki, 2014; National Scientific Council on the Developing Child, 2005). War and famine experienced during early adolescence (10-14 years of age) are "even more strongly associated with a decrease in total lifespan than stressors experienced at any other age of childhood" (Falconi et al., cited in Dahl \& Suleiman, 2017, pp. 22-23). Education inequality is associated with an increased likelihood of violent conflict (Omoeva \& Buckner, 2015); violent conflict in return further exacerbates inequality in education and other socioeconomic outcomes (Omoeva, Hatch, \& Moussa, 2016).

In economic terms, the cost of violent conflict is also astounding. Countries at war "lose an average 8.5 percentage points in economic growth in the first year of civil war and $4.5 \%$ in subsequent years. These effects persist for several years following the end of hostilities" (UN \& World Bank Group, 2017, p. 1). The cost of containing violence has been estimated to be at:

“... US\$13.6 trillion a year globally, a figure ... equivalent to 13.3 [percent] of world GDP or US $\$ 1,876$ PPP [purchasing power parity] per annum, per person.... To further break it down, that figure is US $\$ 5$ per person, per day, every day of the year. When you consider that according to the most recent World Bank estimates 10.7 [percent] of the world's population are living on less than US\$2 per day, it shows an alarming market failure." (IEP, Schippa, cited in UN \& World Bank Group, 2018, p. 33)

Prevention measures could safeguard between USD 5 billion and 70 billion per annum (Mueller, cited in UN \& World Bank Group, 2017, p. 4). 


\subsection{Child Development and Protection Prerequisites for Sustainable Peace}

Numerous resolutions and protocols acknowledge the importance of child protection and development programming as a prerequisite for sustainable peace. Psychological and neuroscientific evidence also stresses the importance of social support structures that protect children against excessive stress and the risks of violence.

\subsubsection{UN Resolutions on Child Well-Being and Conflict Prevention}

Both the United Nations General Assembly [UNGA] and the United Nations Security Council [UNSC] acknowledge the link between child protection, child development, and conflict prevention. Resolution 2427 emphasizes that:

“... a strong focus is needed on combatting poverty, deprivation and inequality to prevent and protect children from all violations and abuses in particular in the context of armed conflict and to promote the resilience of children, their families and their communities, and the importance of promoting education for all and peaceful and inclusive societies for sustainable development." (United Nations Security Council [UNSC], 2018b, p. 1)

UNSC Resolutions 2250 and 2419 recognize how the disruption of youth's access to education and economic opportunities dramatically impacts durable peace and reconciliation while at the same time acknowledging the "important and positive contribution of youth in efforts for the maintenance and promotion of peace and security" (UNSC, 2015, p. 1).

Article 29d of the Convention of the Rights of the Child (UNGA, 1989) calls for "the preparation of the child for responsible life in a free society, in the spirit of understanding, peace, tolerance, equality of sexes, and friendship among all peoples, ethnic, national and religious groups and persons of indigenous origin." The 2030 Agenda for Sustainable Development highlights the interconnectedness between sustainable development, education, and peace (United Nations, 2015, p. 2; Goals 4.7 \& 16). The twin Sustaining Peace Resolutions endorsed by both the UNGA and UNSC (2015), as well as the review of Resolution 1325 (UN Women's Organization, 2015), request that all UN agencies contribute to sustaining peace, for social services to be leveraged for peacebuilding, and for paying special attention to the role of women in peacebuilding.

\subsubsection{Basic Human Needs, Altruism, and Aggression}

Children's ability to evolve into caring, non-violent, and optimally functioning citizens depends on family, school, community, and macro-political contexts that allow for the constructive satisfaction of basic human needs - safety and security, 
effectiveness and control, comprehension of reality, positive identity, positive belonging, as well as independence and autonomy (Staub, 2003, pp. 52-67). "Optimally functioning persons" are children and youth who have "their basic needs fulfilled to a reasonable extent, and who have developed the capacity to fulfill needs in constructive rather than destructive ways, and who have experienced a continuous evolution of effectiveness and identity and connection as a result of the continued fulfillment of these needs" (Staub, cited in Affolter, 2005, p. 382). Although development discourse communities have historically overlooked the psychosocial relevance of their aid and development interventions (Affolter, 2004, 2005), evidence is accumulating to show that societies that offer more education, employment, livelihood, and political engagement opportunities, as well as social mobility opportunities for young people - thereby addressing both socioeconomic and psychosocial needs of populations - tend to experience less violence (Idris, 2016; Paasonen \& Urdal, 2016; Staub, 2011). Some evidence suggests that the best predictor of a state's peacefulness might be "how well women are treated, rather than the status of wealth, democracy, ethnicity, or religious identity" (Caprioli, cited in UNICEF, 2016b, p. 2). Similarly, early childhood development interventions are increasingly documented to provide a potential pathway to violence reduction as well as family and community transformation (Richter, Lye, \& Proulx, 2018; Leckman, Panther-Brick, \& Salah, 2014).

\subsection{UNICEF's Peacebuilding, Education, and Advocacy Programme [Learning for Peace]}

It is in this context that lessons learned from UNICEF's 2012-2016 "Learning for Peace" programme ${ }^{1}$ offer valuable insights on how social services - education in this case - can be leveraged to contribute to the mitigation of conflict factors, and for strengthening social integration and cohesion, while at the same time ensuring the safeguarding of children's developmental and cultural needs and rights.

UNICEF (2016c) defines social cohesion as "the quality of bonds and dynamics that exist between ... groups within a society" (p. 12). UNICEF recognizes in social cohesion one critical dimension of peace which - in order to become sustainable must be combined with the availability and access to economic resources, information and communication, justice, security, leadership and positive governance, as

\footnotetext{
1 "Learning for Peace" (also known as the "Peacebuilding, Education and Advocacy in ConflictAffected Context Programme" or PBEA) was funded by the Government of the Netherlands and implemented by UNICEF from 2012 to 2016. It emerged from the "Education in Emergencies and Post-Crisis Transition Programme" whose final program evaluation called for emergency interventions that address the root causes of conflict and fragility (UNICEF, 2015a, p. 16). Research and program evaluation reports as well as education-for-peacebuilding guidance notes produced under the "Learning for Peace" programme, can be accessed on USAID's Education in Crisis and Conflict Network [ECCN] website at https://eccnetwork.net/resources/learning-for-peace/ and on the website of the International Network for Education in Emergencies (INEE) at http://www. ineesite.org/en/learning-for-peace.
} 
well as an ability to constructively deal with conflict legacies of the past (UNICEF, 2016c; see also Pham \& Vinck, 2017, pp. 12ff.). The unequitable, non-transparent, nonaccountable, or incompetent administration of social services, however, can prompt affected identity groups to suspect deliberate acts of discrimination (McCandless, 2012, p. 9; World Bank Group, 2011, p. 88), thereby fuelling resentment and aggravating "social erosion" dynamics. According to Larsen (2014, pp. 2-3), social erosion occurs when the number of citizens sharing beliefs that enable them to trust one another declines. Social erosion can be mitigated, however, whenever social service providers make use of the opportunity to design and administer service interventions in ways that facilitate "social integration," which is a precursor to social cohesion (Larsen, 2014, p. 2).

While the "Learning for Peace" interventions introduced below do not provide quantitative evidence from impact evaluations for justifying the claim that they have impacted community or national trust levels, evidence from programme monitoring, case studies, and other research designs nonetheless suggests that they contributed to facilitating social integration, cooperation, inclusion, trust, and participation among citizens and citizen groups whose relationships were previously eroded (UNICEF, 2016c). For example, in rural communities in Côte d'Ivoire where interethnic relations had deteriorated as a result of decade-long electoral violence, the operationalization of inclusive early childhood development services and women adult literacy services in 16 villages succeeded in cultivating trust, solidarity, and community engagement first among women and later also fathers from diverse ethnic backgrounds. In Burundi, returnees and host communities reorganized around school social platforms. In Pakistan, Afghan refugee girls were able to access education services in neighboring host communities, and madrasa students joined extracurricular sports and arts events together with children from public schools.

An independent evaluation of "Learning for Peace" concluded that UNICEF's decision to leverage social services for peacebuilding purposes was feasible and that the initiative's "emphasis on conflict analysis based programming... leads to responsive context-specific programmes that can contribute to peacebuilding" (UNICEF, 2015a p. xiv).

"Learning for Peace" was implemented in 14 conflict-affected contexts (Burundi, Chad, Côte d'Ivoire, Democratic Republic of Congo, Ethiopia, Liberia, Myanmar, Pakistan, State of Palestine, Sierra Leone, Somalia, South Sudan, Uganda, and Yemen). It aimed, at a minimum, to make education and other social services based on conflict analyses which incorporated a focus on the education sector conflict-sensitive toward existing conflict factors ("do-no-harm") and where possible to contribute to their mitigation ("do-more-good").

As illustrated in Fig. 14.1, "Learning for Peace" used a systemic approach to education for peacebuilding, going beyond traditional "peace education" approaches. This could include - at the macro level - education policies and sector plans, curriculum framework development, teacher recruitment and school construction contracting policies, equitable education resource distribution, as well as institutional and staff capacity development inside ministries. In addition, it included capacity development for education agencies and religious and community organizations at the meso level, as well as parents and children at the micro level. Far from suggesting 


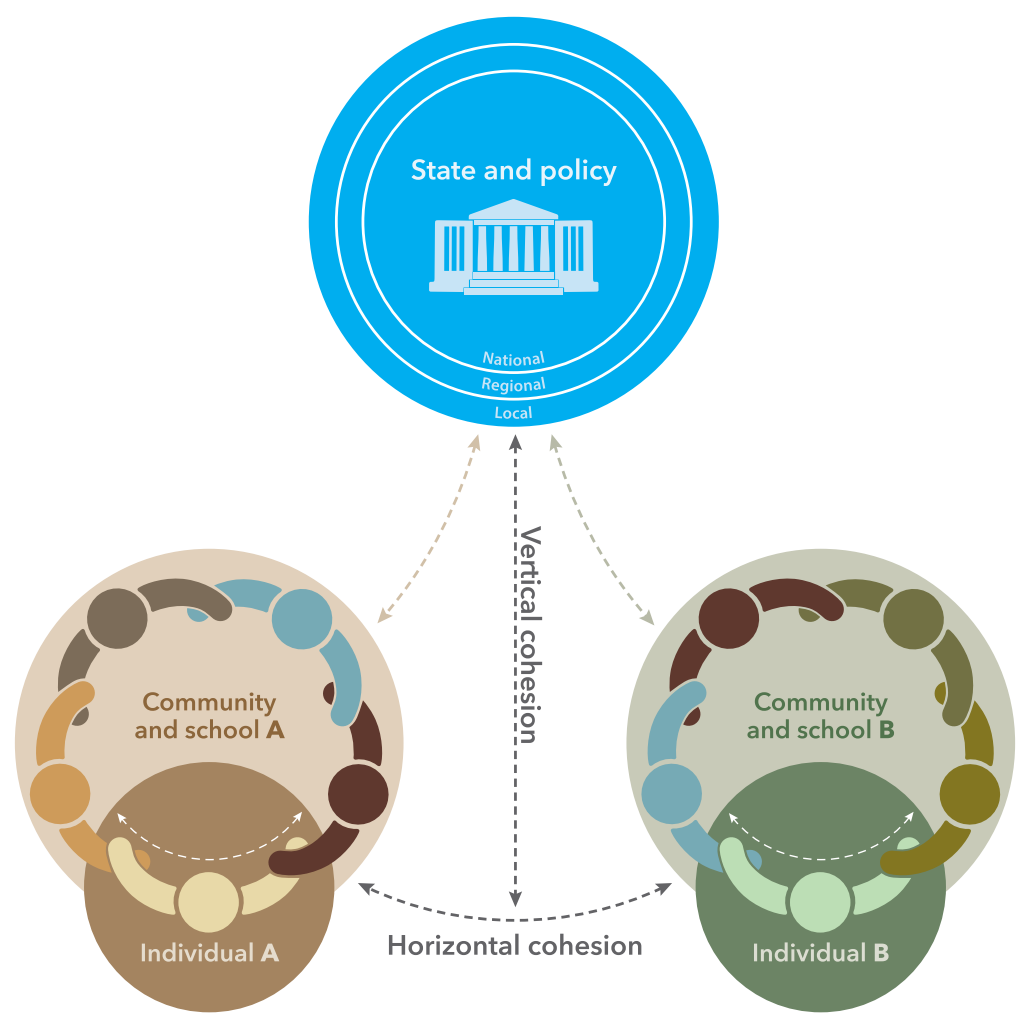

Fig. 14.1 Peacebuilding education for vertical and horizontal social cohesion. (Source: UNICEF, 2018)

that the education sector alone has the capacity to fully and independently mitigate conflict factors - this requires cross-sectoral socioeconomic and political interventions at multiple levels of the human ecology - "Learning for Peace" attempted to design education interventions to contribute to the mitigation of conflict drivers either by strengthening horizontal relationships between individuals and groups, or vertical relationships between government institutions and citizenry (UNICEF, 2016a).

\subsection{Theoretical Framework for Understanding Education in Conflict and Peace and Education for Peacebuilding Programming}

Education sector policies and structures can be designed to contribute to the mitigation of education-related conflict factors and for facilitating social integration. Drawing on earlier work of Nancy Frazer, Johan Galtung, and Jean-Paul Lederach and based on additional country-level research conducted in "Learning for Peace" programme countries - Novelli, Lopes Cardozo, and Smith (2015) proposed a 4 Rs Analytical Framework (see Fig. 14.2) for analyzing the contribution of education 


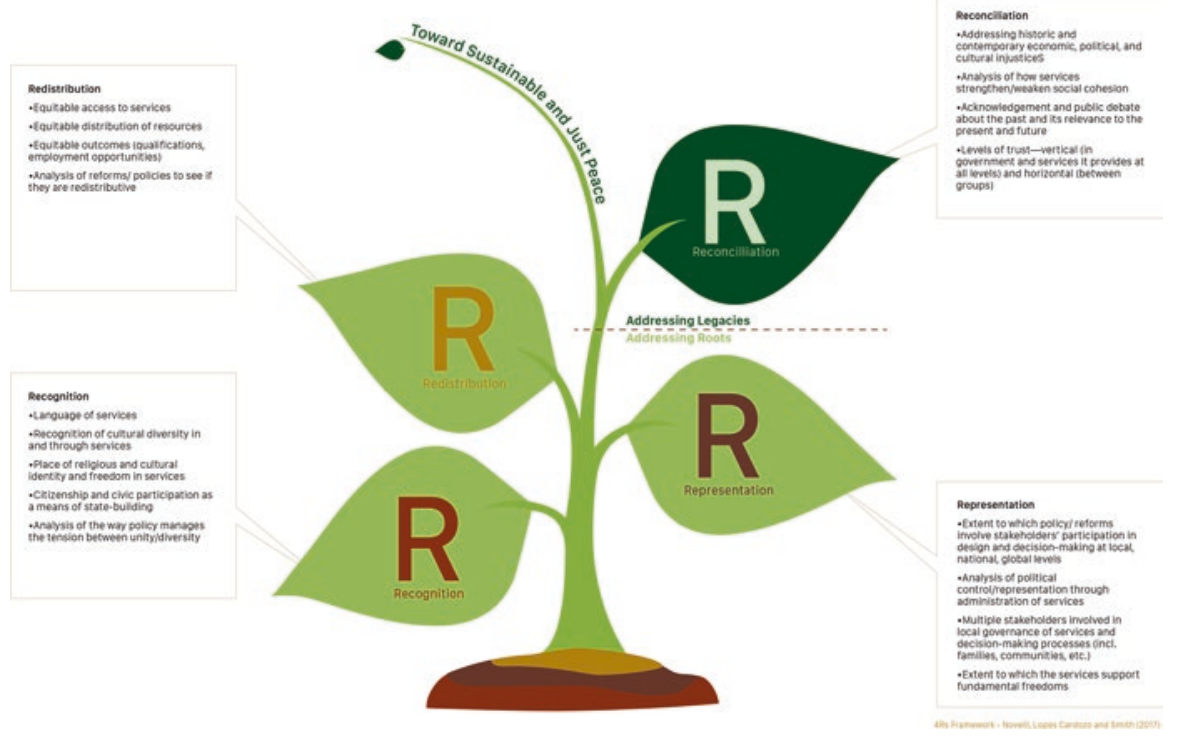

Fig. 14.2 Sustainable peacebuilding in education: The "4 Rs" analytical framework

services to sustainable peacebuilding. Although the education sector alone is not a panacea for peacebuilding - indeed, education systems can and have been "hijacked" in the past to polarize and antagonize societies (Bush \& Saltarelli, 2000) - education services can be leveraged to work in tandem with other political, socioeconomic, psychological, and cultural empowerment efforts. In order to do this, governments and education actors need to ensure (a) the equitable redistribution of education resources and opportunities; (b) the recognition of the diverse education needs of identity groups; (c) the participation as well as the social and political representation in education decision-making processes; as well as (d) the use of education social platforms for reconciliation learning. The framework also recognizes the complex interaction between the "4 Rs."

In the remainder of this chapter, conflict analysis and research findings, as well as anecdotal evidence from "Learning for Peace" programme reports (peacebuilding-oriented education policies, institutional capacity development, as well as community interventions), will be presented in relation to each of the $4 \mathrm{R}$ categories, thereby illustrating possibilities and limitations of education programming efforts for vertical and horizontal social cohesion and the mitigation of conflict causes.

\subsubsection{Redistribution of Education Resources: To Counter Education Inequities and Inequalities}

Poverty, low levels of development, and inequitable economic development are frequently cited as conflict factors in PBEA country conflict analyses (for conflict analysis summaries, see Learning for Peace, 2018). Frustration and tension were found to be increased by negligible economic diversification, poor infrastructure, 
and unfair distribution of or lack of relevant educational opportunities, particularly in the formal sector.

The link between education inequality and violent conflict has been corroborated by research conducted by FHI 360 on behalf of UNICEF. Omoeva and Buckner (2015) examined horizontal education inequality between culturally defined or constructed groups and socioeconomic divisions (e.g., ethnic, religious, etc.) by comparing education equality data and conflict data from nearly 100 countries over the past 50 years. They generated robust evidence that the likelihood of violent conflict doubles for countries with high levels of intergroup inequality in education (after controlling for known conflict risk factors such as wealth, political regime, geography, etc.). The research also suggests that greater education equality between male and female students decreases the likelihood of conflict by as much as 37\%. Similarly, Omoeva et al. (2016) found that conflict widens education inequalities among groups and individuals, with lower wealth-based groups and gender disparities particularly impacted. The longer the conflict, the harder it becomes to return to pre-conflict levels of inequality, and the more relapses to the conflict there are, the more the gap widens between post-conflict inequality and pre-conflict inequality.

Under "Learning for Peace," education programs have been designed to address the mitigation of inequalities. In northern Burundi, conflict risks resulting from the arrival of returnees from the Mtabila Camps in the United Republic of Tanzania resulted in host communities' inability to provide education opportunities for all. UNICEF supported the construction of classrooms in communities predominantly consisting of returnees and where community members had provided the land or contributed labor to produce ecologically friendly materials. As a result, returnee children were able to access education alongside children of host communities, and the damaging consequences of remaining out of school were avoided. The shared school construction process also increased solidarity among returnees and community members. Conflict sensitivity principles such as respect, inclusiveness, impartiality, transparency, accountability, and ownership were applied to facilitate the involvement of community members, neighbors, and returnees and ultimately increased community cohesion. As refugee returns continued to be a source of concern in a number of provinces in Burundi - many of those returning had no meaningful connection with their communities of origin - education programs proved to be a meaningful platform to build relationships, notwithstanding austerity and distress (UNICEF Burundi, 2016).

In Pakistan's provinces of Baluchistan and Sindh, as well as the Federally Administered Tribal Areas, the UNICEF Pakistan Country Office supported Alternate Learning Programmes (ALPs) in hard-to-reach and conflict-prone areas, benefiting more than 16,000 out-of-school children ( $48 \%$ girls) who otherwise would have grown up without access to quality education services. A refugee inclusion project promoting interaction between children from host communities and out-of-school boys and girls from Afghan refugee camps showed a significant 25\% increase in the enrolment of refugee children in public schools of Baluchistan, Khyber Pakhtunkhwa, and Sindh provinces. Enrolment of Afghan girls also increased by 17\% (UNICEF Pakistan, 2016). 
In the Democratic Republic of Congo, a Policy Dialogue Forum supported the development of a new Education Sector Plan that stressed the need of equity, conflict sensitivity, new citizenship, and emergency education in the government's new sectoral education and training strategy (République Démocratique du Congo, 2014). Similarly, the education sector plans of Côte d'Ivoire (République de Côte d'Ivoire - Ministère de l'Education Nationale, 2017) and Pakistan's Sindh province (Government of Sindh, 2014 p. 263) acknowledged the risk of conflict resulting from unequal access to opportunities and resources.

\subsubsection{Recognition: Of Identity, Voices, and Needs}

Ethnic and religious divisions - mobilized along political lines and emphasizing grievances in terms of inequalities between groups - are often also reinforced through the education sector. In Myanmar, "Burmanization" caused resentment among ethnic minority groups. In Baluchistan and Gilgit-Baltistan in Pakistan, feelings of resentment emanated from a perception of ethnic discrimination. Conflict analysis research commissioned under "Learning for Peace" also highlights the unmet needs of a growing youth population with limited prospects of employment or participation in civil society (Learning for Peace, 2018). The marginalization of youth voices, identities, and needs is also evident in education sector plans analyzed in a comparative case study analysis that included the countries of Myanmar, Pakistan, South Africa, and Uganda (Lopes Cardozo, Higgins, \& Le Mat, 2016).

In the Eastern Asia and Pacific Region (Malaysia, Myanmar, and Thailand), UNICEF in partnership with the University of Melbourne launched a Language Education and Social Cohesion [LESC] initiative to study and address the risks associated with language and ethnicity issues that children face in educational and non-educational settings. A key finding of the LESC initiative is that conventional analyses of conflict have underestimated the role of language and ethnicity differences in instigating conflicts, as well as in sustaining conflicts once they have commenced. Language becomes a slow-acting conflict instigator wherever policies are used to discriminate minorities and a fast-acting instigator where it is used for exclusionary, stigmatizing, or inflammatory speech against minority groups (LoBianco, 2016, p. 14). In Myanmar, LESC's approach to leverage language policy for conflict mitigation consisted in the establishment of language planning platforms where stakeholders from both government and ethnic minority groups came together for the first time to jointly reflect and engage with critical language policy issues and to devise policy recommendations for mitigating conflict risks related to cultural rights and social identity (LoBianco, 2016). LESC also aimed to align language-related education policy with national education sector plans, since child early learning and literacy in the mother tongue is a prerequisite for the effective 
acquisition of other national languages (Abadzi, 2006, pp. 50-57) and thus a building block for mitigating the risks of education inequality in Myanmar:

\begin{abstract}
A high rate of functional literacy can help a child gain access to cultural capital, to material success through better skills acquisition, and to enhanced employability. It is a critical part of a quality education, and it improves children's chances of experiencing better health and social well-being throughout their lives. A well-educated child is also more likely to participate actively and constructively in decision-making processes and therefore to become an asset in national political processes. (Toole, in LoBianco, 2016, p. 1)
\end{abstract}

In Somalia, marginalization of youth has been recognized as a salient driver of conflict (Learning for Peace, 2018). Youth are frequently uneducated; excluded from political, economic, and social processes; and unable to access suitable employment for gaining an independent livelihood. As a consequence, marginalized youth may choose to join religious or freelance armed or criminal groups. In 2014, the Somali Federal Government, in partnership with UN agencies, decided to conduct a school curriculum review that would take into account the values and aspirations expressed by youth and elders of rural communities. A community-based consultative process was launched, which included 248 young Somali men and women who held focus group interviews with youth and community elders to inquire which values and competencies Somali learners should acquire across different subjects taught. The findings were presented to the government and served the purpose of developing a new curriculum framework that was more reflective of community voices as well as more context-relevant. In addition, the programme created a social platform for youth to participate in a national decision-making process that will impact education programming in Somalia for years to come. Youth researchers have been publicly valued by education officials, education stakeholders, and community leaders. The Government of Somalia recognized the education sector's potential contributions toward social cohesion and peacebuilding, in particular when it comes to issues of equity, inclusion, and livelihood opportunities for young people in Somalia (Renders \& Knezevic, 2017).

\title{
14.4.3 Representation: Participation in Decision-Making
}

Conflict analyses across PBEA countries illustrated that weak governance - characterized by divided politics, limited policies and legislation, inadequate local capacity to guarantee for safety and security, political corruption and exclusion, as well as the centralization of power and resources - is a predominant driver of conflict (Learning for Peace, 2018). Education systems frequently reflect governance weaknesses and fail to provide social spaces for youth, teachers, and minority groups (Smith, Marks, Novelli, Valiente, \& Scandurra, 2016). In Kenya's semi-arid regions, for example, education systems embedded in tribal and political power struggles are ill-prepared to assist youth from pastoralist backgrounds to develop critical thinking and leadership skills necessary for mitigating divisive identity politics. Programs that strengthen pastoralist resilience and development learning are absent. Instead, 
"underemployed young people often dissociate with local politics, and - feeling that they are not full citizens of Kenya - turn towards religious, martial or criminal identities that seem to be a better fit for coping with a politicized and violent society" (Scott-Villiers, Wilson, Molu Kullu, Ndung'u, \& Scott-Villiers, 2015, p. 65).

Education can become a vehicle for peacebuilding when serving as a consultation platform where dialogue, participation, and representation become possible. This was illustrated in the abovementioned Myanmar example where ethnic minority groups were invited to negotiate minority language policy together with experts and government representatives, and in the example from Somalia where curriculum reform reflected community recommendations that were collected by youth action research facilitators.

In Uganda, the "Learning for Peace" programme has put in use the SMS-based U-Report technology to enable more than 300,000 youth to make their voices heard on consultation platforms dedicated to the discussion of social development issues and in which members of Parliament also did participate. U-Report enables participants to ask questions, voice opinions, and provide feedback about policy decisions, advocate for community rights, and inquire or become acquainted about the availability of social service mechanisms. When the Office of the Prime Minister initiated in 2015 a redrafting of a new peace policy for Uganda, U-Report facilitated the provision of inputs of 40,000 young people on the type of matters youth thought necessary to be addressed in the new Uganda Peace Policy. (An initial draft was prepared in 2012, where youth voices had not been consulted.) U-Report Uganda also supported the Uganda Civil Society Youth Coalition that brings together more than 375 youth-led and youth-serving community-based and civil society organizations utilizing U-Reporter feedback. For the Ugandan government, U-Report platforms provided the opportunity to "stay in touch" with youth voices and sentiments. They increased the government's appreciation of youth perspectives for policy discourse and program development and young people as potential partners in consultations relating to social services programming, as well as nation building (UNICEF Uganda, 2016, p. 22).

When it comes to gender relationships in conflict and post-conflict countries, norms that condone sexual and gender-based violence often undermine stability and present an additional security risk in communities and states - even after conflict has officially ended (Blair, Gerring, \& Karrim, 2016, p. 1; UNICEF, 2016b; El-Bushra \& Rees-Smith, 2016; see also von Joeden-Forgey, 2016, pp. 129-130). In Somalia and South Sudan, UNICEF's "Communities Care" project used two mutually reinforcing strategies: (1) strengthening care and support for survivors of gender-based violence, particularly survivors of sexual violence, and (2) engaging communities in collective action to prevent sexual violence.

Facilitating participatory dialogue among stakeholders was the key strategy of the "Communities Care" programme for catalyzing community-led action toward the mitigation of gender-based violence in rural communities. In this process, female and male community members, elders, religious leaders, leaders of camps for internally displaced populations, youth leaders, health workers, police, teachers, students' parents, and school administrators were involved in structured meetings 
that were held twice a week over the course of 15 weeks to discuss and reflect on core values such as fairness, justice, and equality. After the dialogues, Communities Care supported participants to take action, including (a) working with fathers and husbands on how to support daughters and wives who are survivors of sexual violence; (b) encouraging religious leaders to take a public stance against sexual violence with their congregants; (c) urging local officials to strengthen laws and policies to reduce impunity for perpetrators; (d) supporting girls and boys to access education; and (e) men and boys demonstrating respect for women and girls by participating in household duties.

More than 1000 people participated in "Communities Care" discussions, and more than 42,000 citizens became involved in community action and engagement events in both Somalia and South Sudan. The midline study and preliminary anecdotal and monitoring data suggest that the programme has provided a platform for identifying community-level solutions for use in conflict and post-conflict settings to address individual and collective conflict vulnerabilities and hazards while simultaneously building on their existing capacities as community leaders and activists (Read-Hamilton \& Marsh, 2016).

\subsubsection{Reconciliation}

Societies with histories of conflict endeavoring to engage in processes of economic and social reconstruction incur the risk of conflict relapse should they choose not to address past human rights abuses or other forms of severe trauma (Ramírez-Barat \& Duthie, 2015, p. 1). Transitional justice processes that promote accountability and redress for human rights violations present an essential element to prevent recurrence of violations and the integration of victims into communities and societies.

Recognizing that post-conflict development and reconstruction frameworks often ignore the role education plays in legacies of past human rights violations, the International Center for Transitional Justice [ICTJ] in partnership with UNICEF commissioned 17 case studies to determine whether and how education can play a role in a society's formulation of constructive responses to human rights violation histories. The research findings are published in the book Transitional Justice and Education: Learning Peace (Ramírez-Barat \& Duthie, 2016). The volume documents truth commissions' efforts to illustrate how education has contributed to conflict in the past, as well as efforts to produce and educate the public by sharing transitional justice education materials and tools with schools and universities. The study furthermore contains examples of curriculum reform as well as teacher training and support for "teaching the past," examples of reparations programs that provide redress through educational assistance to victims or their family members, as well as nonformal education projects addressing the legacies of the past. The study concludes that it is possible and in specific contexts feasible to include education sector programming into a societal response to past human rights violations, as long as it is recognized that such processes must be context-specific, risk-informed, 
conflict-sensitive, consultative, and long-term. Efforts to leverage education for transitional justice processes need to be complemented by broad reforms in other areas, as well as investments in reconstruction and peacebuilding (Ramírez-Barat \& Duthie, 2015, 2016).

Supporting reconciliation efforts through a transitional justice lens was attempted by "Learning for Peace" but - apart from the abovementioned research project with only moderate results. Governments of fragile states are weary and often lack the resilience necessary to withstand the risks and shocks that may emanate from touching on painful memories from the past. Even if a government has come into power with a strong voter mandate, the willingness to acknowledge past injustices and human rights violations always risks the emergence of fissures within institutions and societies which could diminish the positionality of government representatives among stakeholder groups.

Notwithstanding, in Côte d'Ivoire - where political rule nurtured and exploited resentment against ethnic minorities - UNICEF and ICTJ assisted the government in the development of a safe and effective methodology for gathering statements of children and young people witnessing human rights violations. A collaborative link between the commission and the education sector, however, could not be established. UNICEF and ICTJ successfully supported youth platforms organizing truthtelling events within their existing networks and subsequently radio campaigns that highlighted how the politicization of universities and schools directly influenced conflict dynamics in Côte d'Ivoire (Ladisch \& Rice, 2016, pp. 368, 372 \& 375).

Also in Côte d'Ivoire, a UNICEF/CARITAS kindergarten programme accessible to families from diverse ethnic groups in conflict-affected rural communities succeeded in establishing relationships of trust between mothers from antagonized ethnic groups. A complementary literacy and livelihood project for these mothers provided additional platforms for dialogue and social exchange - first among mothers and later also among fathers, some of whom were active supporters of political parties supporting the conflict on different sides. The programme eventually cemented horizontal social cohesion in 16 conflict-affected villages where there was none previously. This case study is noteworthy because it demonstrates that early childhood development services can be leveraged to strengthen community cohesion, thereby mitigating structural violence which in return has positive implications for stress reduction and early childhood development (Learning for Peace, 2018). Morgan et al. (2014) suspect that the reduction of structural violence is possibly far more relevant for early child protection and peacebuilding and can accomplish far more than early childhood development interventions aiming to buffer the impacts of toxic stress (p. 125).

Many of the earlier mentioned "Learning for Peace" project examples Myanmar's LESC (LoBianco, 2016), Somalia's youth supporting the development of a new curriculum framework (Renders \& Knezevic, 2017), and Somalia's and South Sudan's “Communities Care" project (Read-Hamilton \& Marsh, 2016) - succeeded in increasing trust between groups and institutions, however, modestly. While trustbuilding is a significant component of reconciliation and thus noteworthy, it remains 
insufficient, however, without the opening of social platforms and the facilitation of acknowledgments of injustices that have occurred in the past.

\subsection{Assessing Education for Peacebuilding Interventions}

Measuring changes resulting from a peacebuilding program intervention remains challenging as the desired peacebuilding change is often less tangible and longterm. In order to measure the prevention of conflict, for example, one would have to prove the causation of "non-events," e.g., the successful avoidance of something which did not occur (Menkhaus, 2004, p. 5). Chigas, Church, and Corlazzoli (2014) argue that it is:

“... much easier to make causal linkages in short results chains-e.g., when the number steps or changes between the activities implemented and the impacts is small. The diverse types of activities conducted for peacebuilding-from dialogue and reconciliation programmes to reintegration of ex-combatants, justice, reform, infrastructure, development and livelihoods - do not all work directly on conflict and peace, but rather seek to affect conflict and peace drivers indirectly. Evaluating this impact entails examining an intervention not only in terms of its own objectives, but (also) in terms of actual outcomes as related to key drivers of conflict and peace. This creates longer and more complex causal chains and makes it impossible to make defensible judgements about sole attribution.” (p. 6)

In order to assess the association of education services with existing levels of horizontal and vertical social cohesion, UNICEF partnered with Harvard Humanitarian Institute (HHI) in developing and pilot testing an Education, Peacebuilding and Social Cohesion Assessment Framework (EPSC) (Pham \& Vinck, 2017; see Fig. 14.3). The Framework has six dimensions: (a) social cohesion; (b) leadership, good governance, and inclusive politics; (c) access to resources and opportunities; (d) the legacies of past conflict; (e) information and communication networks; and (f) justice and security. These dimensions were identified as relevant during scoping assessments in Burundi, DRC, Côte d'Ivoire, and Uganda where different categories of local stakeholders were queried about their understanding and awareness of social cohesion challenges and prerequisites in their own community and regional contexts. The EPSC contains contextualized specific indices to measure cohesion factors such as trust, social relationships, civic and social participation, inclusion, and attitudes toward social services, as well as constructive dispute resolution. Where possible, the EPSC measured the relationships between teachers, parents, students, and community members, as well as social cohesion factors before and after an education intervention (Pham \& Vinck, 2017).

Although it is difficult to measure attribution of social service delivery (such as education) to peacebuilding - due to the fluctuation of uncontrolled elements in fragile contexts (i.e., breakout of violent conflict, changes in political regimes, natural disasters, and economic shocks, all of which co-influence causal chains) - the assessments conducted in Burundi, Côte d'Ivoire, DRC, and Uganda demonstrate 


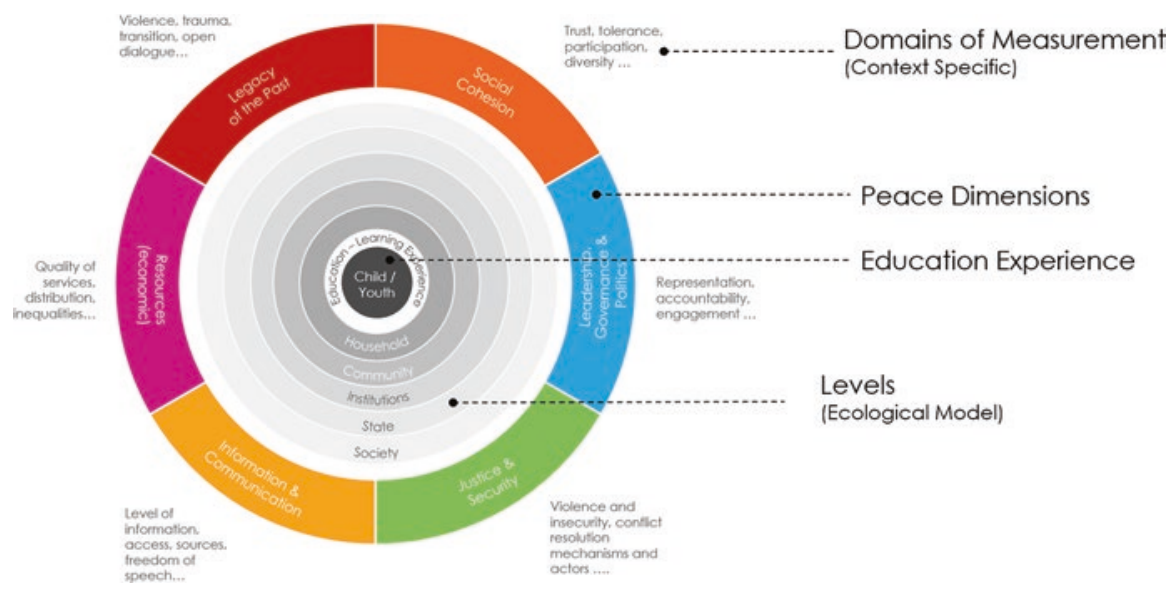

Fig. 14.3 Education, Peacebuilding and Social Cohesion Assessment Framework [EPSC] (Pham \& Vinck, 2017, p. 12)

that it is possible to measure and even map an "association" of existing (or nonexisting) social service components with varying degrees of social cohesion or a prevalence of conflict factors and to compare these with cohesion and social service statistics in alternative geographies (Pham \& Vinck, 2017). The EPSC can serve to assess the degree of stability or fragility of relationships, and to juxtapose this analysis with the availability and quality of social services (such as education but also health, water and hygiene, nutrition, or protection services) in fragile and postconflict settings. It can be used to determine social integration intervention priorities and to measure changes once an intervention is under implementation or at the end of an implementation phase.

One of the key takeaways from the HHI analyses and other monitoring and evaluation efforts employed by country offices is that the choice of instruments, the analysis process, and the interpretation of the results must include consultations and validation with local actors who can interpret the results, triangulate findings using qualitative data sources, and identify consistencies and inconsistencies based on contextual knowledge. For example, young people in Côte d'Ivoire, Uganda, Sierra Leone, and Burundi were assisted in using participatory video tools for the documentation of their own "Most Significant Change" experiences occurring in times of violent conflict (see InsightShare, 2018a). Together with local facilitators, young people formed evaluation teams and co-designed evaluation processes of youth-led peace and transitional justice efforts in Côte d'Ivoire; sustainable livelihood programmes for youth in Karamoja, Uganda; child-friendly schools and youth-led peace interventions in Sierra Leonean communal conflict settings; and the communication of Ubuntu values among returnees and host community members in Burundi (InsightShare, 2018b). 


\subsection{Conclusion: Learning for Peace}

Prevention of violent conflict remains a critical challenge for progress toward sustainable development for all. Central to this is the need to address grievances around inequities and exclusion from access to power, opportunities, and security (United Nations \& World Bank Group, 2018). Within this context, "Learning for Peace" presented an opportunity to better understand the complex relationship between education, conflict, and peace and reflect on possible ways forward on how education and other social services can be leveraged to better contribute to the mitigation of conflict factors.

Four main messages can be highlighted for national governments, education, and research partners moving forward. First, it is critical to prioritize investments in education and other social services before, during, and after conflict. The narrow emphasis on security, financial, and political systems - while necessary - is not sufficient to address the underlying grievances linked to exclusion and social injustice. Social services provide opportunities to begin addressing the underlying causes of conflict and building and sustaining peace. Education, in particular, is a unique vehicle to influence the growing younger generations, their caregivers, and supportive communities to collaboratively build resilient and peaceful societies.

Second, as demonstrated by education-focused conflict analyses conducted through "Learning for Peace," in societies where societal social capital is weakened by crises and violence and where trust and relationships are broken, education does not remain neutral. Education systems, institutions, and programs can either aggravate existing tensions and create new grievances or support rebuilding the social fabric and social capital. It is therefore critical to ensure that education planning and delivery recognizes and responds to the conflict dynamics and in doing so addresses the issues of equity, transparency, quality, and relevance of education services.

Third, "Learning for Peace" has demonstrated across diverse country contexts that children and young people - as well as their families, caregivers, and service providers - are critical partners and agents of change. Children and young people in particular proactively engage in building peaceful communities and can make important contributions to reconciliation and reconstruction processes when presented with participation and engagement opportunities. It is therefore important to expand the participation of the younger generations in peacebuilding efforts and processes and proactively examine how formal and nonformal education can support their agency and capacity for leadership.

Finally, there is a need for continued research and evidence building on the role of education in contributing to social cohesion. While Learning for Peace provided opportunities to develop and test methodological approaches and document select programmatic initiatives and longer-term investments in qualitative and mixed methods, participatory and locally led research is necessary to better understand what contribution education can make toward strengthening resilience and social cohesion of societies within the broader social, political, and economic transformation processes across diverse country contexts. 


\section{References}

Abadzi, H. (2006, June 20). Efficient learning for the poor: Insights from the frontier of cognitive neuroscience. Washington, D.C.: The World Bank. Retrieved from http:// documents.worldbank.org/curated/en/438221468134385073/Efficient-learning-for-the-poorinsights-from-the-frontier-of-cognitive-neuroscience

Affolter, F. W. (2004). On the absence of a 'socio-emotional enablement' discourse component in international socio-economic development thought. Scandinavian Journal for Caring Sciences, 18, 424-436.

Affolter, F. W. (2005). Socio-emotional enablement and the convention of the rights of the child. International Journal of Children's Rights, 13, 378-397.

Black, M., Walker, S. P., Fernald, L. C. H., Anderson, C. T., DiGirolamo, A. G., Lu, C., McCoy, D. M., Fink, G., Shawar, Y. R., Shiffman, J., Devercelli, A. E., Wodon, Q. T., Vargas-Barón, E., Grantham-McGregor, S., \& Lancet Early Childhood Development Series Steering Committee (2017, January 7-13). Early childhood development coming of age: Science through the life course. Lancet, 389, 77-90.

Blair, A. H., Gerring, N., \& Karrim, S. (2016, August). Ending sexual and gender-based violence in war and peace: Recommendations for the next U.S. administration. Washington, D.C.: United States Institute of Peace. Retrieved from https://www.usip.org/sites/default/files/ PB215-Ending-Sexual-and-Gender-Based-Violence-in-War-and-Peace.pdf

Bush, K. D., \& Saltarelli, D. (2000). The two faces of education in ethnic conflict: Towards a peacebuilding education for children. Florence, Italy: UNICEF Innocenti. Retrieved from https://www.unicef-irc.org/publications/pdf/insight4.pdf

Chigas, D., Church, M., \& Corlazzoli, V. (2014, May). Evaluating impacts of peacebuilding interventions: Approaches and methods, challenges and considerations. London, UK: Department for International Development|[DfiD].

Dahl, R., \& Suleiman, A. (2017). Adolescent brain development: Windows of opportunity. In N. Balvin \& P. Banati (Eds.), The adolescent brain: A second window of opportunity. A compendium (pp. 21-28). Florence, Italy: UNICEF Innocenti. Retrieved from https://www. unicef-irc.org/publications/933-the-adolescent-brain-a-second-window-of-opportunity-acompendium.html

Dawes, A., \& van der Merwe, A. (2014). Structural violence and early childhood development. In J. F. Leckman, C. Panter-Brick, \& R. Salah (Eds.), Pathways to peace: The transformative power of children and families (pp. 233-250). Cambridge, MA: The MIT Press.

El-Bushra, J., \& Rees-Smith, E. (2016). Gender, education and peacebuilding. A review of selected 'learning for peace' case studies. Retrieved from https://eccnetwork.net/wp-content/uploads/ Gender-Education-and-Peacebuilding-A-Review-of-Learning-for-Peace-Case-Studies.pdf

Government of Sindh. (2014). Sindh education sector plan 2014-2018. Karachi, Pakistan: Reform Support Unit, Education and Literacy Department. Retrieved from http://www.sindheducation. gov.pk/Contents/Menu/Final\%20SESP.pdf

Human Rights Council. (2016, February 3). Promotion and protection of all human rights, civil, political, economic, social and cultural rights, including the right to development: Thirty-first session agenda item 3. A/HRC/31/59. Retrieved from http://undocs.org/A/HRC/31/59

Idris, I. (2016). Youth unemployment and violence: Rapid literature review. Birmingham, UK: GSDRC, University of Birmingham. Retrieved from http://gsdrc.org/wp-content/ uploads/2016/11/YouthUnemployment_Violence.pdf

InsightShare. (2018a). Resources: Participatory video and most significant change. Retrieved from http://insightshare.org/resources/participatory-video-and-the-most-significant-change/

InsightShare. (2018b). Projects: Evaluating UNICEF peacebuilding programmes in Africa. Retrieved from http://insightshare.org/projects/evaluating-unicef-peacebuilding-programmes-in-africa/

Kirollos, M., Anning, C., Fylkesnes, G. K., \& Denselow, J. (2018). War on children. London, UK: Save the Children International. Retrieved from https://www.savethechildren.net/waronchildren/pdf/waronchildren.pdf 
Ladisch, V., \& Rice, J. (2016). Addressing the recent past in schools. Reflections from Côte d'Ivoire. In C. Ramírez-Barat \& R. Duthie (Eds.), Transitional justice and education: Learning peace (pp. 363-383). New York, NY: International Centre for Transitional Justice [ICTJ]. Retrieved at https://www.ictj.org/our-work/research/education-peacebuilding

Larsen, C. A. (2014). Social cohesion: Definition, measurement and developments. Aarlborg, Denmark: Institut for Statskundskab, Aalborg Universitet. Retrieved from http://www.un.org/ esa/socdev/egms/docs/2014/LarsenDevelopmentinsocialcohesion.pdf

Learning for Peace. (2018). Conflict analysis. Retrieved from https://eccnetwork.net/resources/ learning-for-peace/conflict-analysis/

Leckman, J. F., Panter-Brick, C. \& Salah, R. (Eds.) (2014). Pathways to peace: The transformative power of children and families. Cambridge: The MIT Press.

LoBianco, J. (2016). Language Education and Social Cohesion (LESC) Initiative in Malaysia, Myanmar and Thailand: Synthesis report. Bangkok, Thailand: UNICEF East Asia and Pacific Regional Office. Retrieved from https://eccnetwork.net/wp-content/uploads/28-Synthesis_ Report_Language_Education_andSocial_Cohesion_Initiative.pdf

Lopes Cardozo, M. T. A., Higgins, S., \& Le Mat, M. L. J. (2016, February). Youth agency and peacebuilding: An analysis of the role of formal and non-formal education. Synthesis report on findings from Myanmar, Pakistan, South Africa and Uganda. Amsterdam, The Netherlands: Research Consortium Education and Peacebuilding, University of Amsterdam. Retrieved from: http://learningforpeace.unicef.org/partners/research-consortium/research-outputs/

McCandless, E. (2012). Peace dividends and beyond: Contributions of administrative and social services to peacebuilding. New York, NY: United Nations Peacebuilding Support Office. Retrieved from http://www.un.org/en/peacebuilding/pbso/pdf/peace_dividends.pdf

Menkhaus, K. (2004, July). Impact assessment in post-conflict peacebuilding challenges and future directions. Retrieved from http://3n589z370e6o2eata9wahfl4.wpengine.netdna-cdn. com/wp-content/uploads/2004/07/2004_WSP_Interpeace_Impact_Assessment_In_Post_ Conflict_Peacebuilding_EN.pdf

Morgan, B., Sunar, D., Carter, C. S., Leckman, J. F., Fry, D. P., Keverne, E. B., ... Olds, D. (2014). Human biological development and peace: Genes, brains, safety, and justice. In J. F. Leckman, C. Panter-Brick, \& R. Salah (Eds.), Pathways to peace: The transformative power of children and families (pp. 95-128). Cambridge, MA: The MIT Press.

National Scientific Council on the Developing Child. (2005). Excessive stress disrupts the architecture of the developing brain (Working Paper No. 3). Cambridge, MA: National Scientific Council on the Developing Child. Retrieved from https://developingchild.harvard.edu/ resources/wp3/

Novelli, M., Lopes Cardozo, M. T. A., \& Smith, A. (2015, January). A theoretical framework for analysing the contribution of education to sustainable peacebuilding: 4Rs in conflict-affected contexts. Amsterdam, Sussex and Ulster: Research Consortium on Education and Peacebuilding and United Nations Children's Fund. Retrieved from http://sro.sussex.ac.uk/58005/

Office of Economic Cooperation and Development [OECD]. (2015). States of fragility 2015: Meeting post-2015 ambitions. Paris, France: OECD Publishing.

Omoeva, C., \& Buckner, E. (2015, April). Does horizontal education inequality lead to violent conflict? A global analysis. Washington, D.C.: FHI360 Global Data Center.

Omoeva, C., Hatch, R., \& Moussa, W. (2016). The effects of armed conflict on educational attainment and inequality. Washington, D.C.: FHI360 Global Data Center.

Paasonen, K., \& Urdal, H. (2016). Youth bulges, exclusion and instability: The role of youth in the Arab Spring. In Conflict Trends (Vol. 3). Oslo, Norway: PRIO. Retrieved from https://www. prio.org/utility/DownloadFile.ashx?id=10\&type=publicationfile

Pham, P. N., \& Vinck, P. (2017, January). Assessment framework for peacebuilding, education and social cohesion. Cambridge: Harvard Humanitarian Initiative. Retrieved from https://eccnetwork.net/wp-content/uploads/19-Social-Cohesion-Assessmen-Framework_20170420-HHI.pdf

Punamäki, R. (2014). Mental health and development among children living in violent conditions: Underlying processes for promoting peace. In J. F. Leckman, C. Panter-Brick, \& R. Salah (Eds.), Pathways to peace: The transformative power of children and families (pp. 213-231). Cambridge, MA: The MIT Press. 
Ramírez-Barat, C., \& Duthie, R. (2015, November). Education and transitional justice: Opportunities and challenges for peacebuilding. New York: International Centre for Transitional Justice [ICTJ]. Retrieved from https://www.ictj.org/sites/default/files/ICTJUNICEF-Report-EducationTJ-2015.pdf

Ramírez-Barat, C., \& Duthie, R. (Eds.). (2016). Education and transitional justice: Learning peace. New York, NY: International Centre for Transitional Justice [ICTJ]. Retrieved from https://www.ictj.org/sites/default/files/ICTJ-UNICEF-Report-EducationTJ-2015.pdf

Read-Hamilton, S., \& Marsh, M. (2016). The communities care programme: Changing social norms to end violence against women and girls in conflict-affected communities. Gender and Development, 24(2), 261-276. Available online at http://preventgbvafrica.org/wp-content/uploads/2016/07/The-Communities-Care-Programme-Changing Social-Norms-to-EndViolence-against-Women-and-Girls-in-Conflict-Affected-Communities.pdf

Renders, M., \& Knezevic, N. (2017). The potential of conflict-sensitive education approaches in fragile countries: The case of curriculum framework reform and youth civic participation in Somalia. Journal on Education in Emergencies, 3(1), 106-128. Retrieved from https://archive. nyu.edu/bitstream/2451/39661/2/JEiE\%20V3\%20_\%20Potential_CSE_Fragile_Countries. Jul\%2017.pdf

République de Côte d'Ivoire - Ministère de l'Education Nationale. (2017, April). Plan sectoriel education/formation 2016 - 2025. Retrieved from https://www.globalpartnership.org/fr/ content/plan-sectoriel-de-leducation-cote-divoire

République Démocratique du Congo. (2014, December). Rapport d'état du système éducatif national: Pour une éducation au service de la croissance et de la paix. Kinshasa: UNICEF, UNESCO - IIEP Pôle de Dakar. Retrieved from http://unesdoc.unesco.org/ images/0023/002326/232623f.pdf

Richter, L. M., Lye, S. J., \& Proulx, K. (2018). Nurturing care for young children under conditions of fragility and conflict. In J. F. Leckman \& P. Britto (Eds.), Towards a more peaceful world: The promise of early childhood development programmes. New directions for child and adolescent development (Vol. 159, pp. 13-26). San Francisco, CA: Jossey-Bass.

Scott-Villiers, P., Wilson, S., Molu Kullu, K., Ndung'u, D., \& Scott-Villiers, A. (2015). A study of education and resilience in Kenya's arid and semi-arid lands: Final report. Nairobi, Kenya: UNICEF UNICEF Eastern and Southern Africa Regional Office (ESARO).

Smith, A., Marks, C., Novelli, M., Valiente, O., \& Scandurra, R. (2016, April). Exploring the linkages between education sector governance, inequity, conflict, and peacebuilding in Kenya: Research report prepared for UNICEF Eastern and Southern Regional Office (ESARO). Nairobi: UNICEF Eastern and Southern Africa Regional Office. Retrieved from https://eccnetwork.net/wp-content/uploads/10-Equity-Education-Peacebuilding-Governance-Kenya.pdf

Staub, E. (2003). Basic human needs and their role in altruism and aggression. In E. Staub (Ed.), The psychology of good and evil: Why children, adults and groups help and harm others (pp. 52-67). New York, NY: Cambridge University Press.

Staub, E. (2011). Overcoming evil: Genocide, violent conflict, and terrorism. Oxford, MI: Oxford University Press.

UNICEF (2015a, November). Evaluation of UNICEF's Peacebuilding, Education and Advocacy Programme (PBEA). Summary. New York: UNICEF. Retrieved from https://eccnetwork.net/ wp-content/uploads/Final-Learning-for-Peace-Evaluation-Summary.pdf

UNICEF. (2015b, December 17). Press release: More than 16 million babies born into conflict this year. New York, NY: UNICEF. Retrieved from https://www.unicef.org/media/media_86560. html

UNICEF. (2016a). Peacebuilding, education and advocacy in conflict-affected contexts programme (PBEA): 2012-2016 programme report. Retrieved from https://eccnetwork.net/wpcontent/uploads/02-UNICEF1020_PBEA-Final-report-A4_web.pdf

UNICEF. (2016b). Gender, education and peacebuilding brief: Emerging issues from 'Learning for Peace'. Retrieved from https://eccnetwork.net/wp-content/uploads/PBEA-Gender_Advocacybrief.pdf 
UNICEF. (2016c, November). Conflict sensitivity and peacebuilding: Programming guide. Retrieved from https://eccnetwork.net/wp-content/uploads/05-Programming-Guide-ConflictSensitivity-and-Peacebuilding-UNICEF-Nov-2016.pdf

UNICEF. (2018). Learning for peace narratives from the field. A compendium of programme strategies 2012/2016. New York, NY: UNICEF. Retrieved from https://eccnetwork.net/wp-content/ uploads/PBEA-case-study-compendium-online-final.pdf

UNICEF Burundi. (2016). Peacebuilding, education and advocacy in conflict-affected contexts programme: Programme report. Unpublished document.

UNICEF Pakistan. (2016). Peacebuilding, education and advocacy in conflict-affected contexts programme: Programme report. Unpublished document.

UNICEF Uganda. (2016). Peacebuilding, education and advocacy in conflict-affected contexts Programme: Programme report. Unpublished document.

United Nations. (2015). Transforming our world: The 2030 agenda for sustainable development. A/RES/70/1. New York, NY: United Nations. Retrieved from http://www.un.org/en/development/desa/population/migration/generalassembly/docs/globalcompact/A_RES_70_1_E.pdf

United Nations \& World Bank Group. (2017). Pathways for peace: Inclusive approaches to preventing violent conflict. Main messages and emerging policy directions. Washington, D.C.: International Bank for Reconstruction and Development/The World Bank. Available online at https://www.openknowledge.worldbank.org/bitstream/handle/10986/28337/211162mm.pdf?s equence $=2 \&$ is Allowed $=\mathrm{y}$

United Nations \& World Bank Group. (2018). Pathways for peace: Inclusive approaches to preventing violent conflict. Washington, D.C.: International Bank for Reconstruction and Development/The World Bank. Available online at https://openknowledge.worldbank.org/ handle/10986/28337

United Nations General Assembly. (1989, November 20). Convention on the rights of the child. A/RES/44/25. New York: United Nations. Retrieved from http://www.un.org/documents/ga/ res/44/a44r025.htm

United Nations General Assembly. (2016, February 3). Report of the special rapporteur in the field of cultural rights. A/HRC/31/59. Retrieved from http://undocs.org/A/HRC/31/59

United Nations General Assembly \& United Nations Security Council (2015, June 30): Challenge of sustaining peace: Report of the advisory group of experts on the review of the peacebuilding architecture. A/69/968 S/2015/490. Retrieved from http://www.un.org/ga/search/view_doc. asp?symbol $=\mathrm{A} / 69 / 968$

United Nations Security Council. (2015, December 9). Resolution 2250 (2015). Adopted by the Security Council at its 7573rd meeting, on 9 December 2015. S/RES/2250 (2015). Retrieved from http://undocs.org/S/RES/2250(2015)

United Nations Security Council. (2018a, June 6). Resolution 2419 (2018). Adopted by the Security Council at its 8277the meeting on 6 June 2018. S/RES/2418 (2018). Available online at: http://undocs.org/S/RES/2419(2018)

United Nations Security Council. (2018b, July 9). Resolution 2427 (2018). Adopted by the Security Council at its 8305th meeting, on 9 July 2018. S/RES/2427 (2018). Retrieved from http://undocs.org/S/RES/2427(2018)

United Nations Women's Organization. (2015). Preventing conflict, transforming justice, securing the peace: A global study on the implementation of United Nations security council resolution 1325. New York, NY: UN Women. Retrieved from http://www.unwomen.org/ /media/files/ un\%20women/wps/highlights/unw-global-study-1325-2015.pdf

von Joeden-Forgey, E. (2016). Gender, sexualized violence and prevention. In S. P. Rosenberg, T. Galis, \& A. Zucker (Eds.), Reconstructing atrocity prevention (pp. 125-148). New York, NY: Cambridge University Press.

World Bank Group. (2011). World development report 2011: Conflict, security and development. Washington, D.C.: International Bank for Reconstruction and Development.

World Economic Forum. (2018). The global risks report 2018. (13th ed.). Retrieved from http:// www3.weforum.org/docs/WEF_GRR18_Report.pdf 
Open Access This chapter is licensed under the terms of the Creative Commons Attribution 4.0 International License (http://creativecommons.org/licenses/by/4.0/), which permits use, sharing, adaptation, distribution and reproduction in any medium or format, as long as you give appropriate credit to the original author(s) and the source, provide a link to the Creative Commons license and indicate if changes were made.

The images or other third party material in this chapter are included in the chapter's Creative Commons license, unless indicated otherwise in a credit line to the material. If material is not included in the chapter's Creative Commons license and your intended use is not permitted by statutory regulation or exceeds the permitted use, you will need to obtain permission directly from the copyright holder. 